\section{Ks. Leszek Misiarczyk}

Uniwersytet Kardynała Stefana Wyszyńskiego

w Warszawie

I.misiarczyk@uksw.edu.pl

ORCID: 0000-0002-9511-6174

DOI: http://dx.doi.org/10.12775/BPTh.2021.002

\section{Biblica}

et

Patristica

Thoruniensia

14 (2021) 1: 41-64

ISSN (print) 1689-5150

ISSN (online) 2450-7059

\title{
Dar języków w czasach apostolskich: glosolalia, ksenoglosja czy jubilacja?
}

\section{The gift of tongues in apostolic times: glossolalia, xenoglossy or jubilation?}

Streszczenie. Jak wykazały analizy, nie ma wątpliwości, że Paweł w 1 Kor 12-14, pisząc o darze języków, miał na myśli glosolalię, czyli mówienie w językach nieistniejących i niezrozumiałych dla nikogo. Na wyrażenie tego daru najczęściej używał zwrotów $\gamma \varepsilon ́ v \eta$

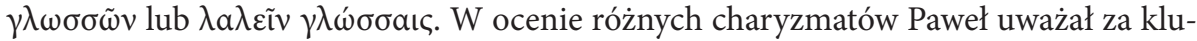
czowe kryterium budowania Kościoła i z tego powodu stawiał wyżej proroctwo niż dar języków. Jeśli jednak darowi języków towarzyszyło wyjaśnienie ( $\dot{\varepsilon} \mu \eta \nu \varepsilon i ́ a ~ \gamma \lambda \omega \sigma \sigma \tilde{\omega} v)$, to wtedy jest on stawiany na równi z proroctwem. Jeśli zaś nie ma osoby obdarowanej charyzmatem wyjaśniania, wtedy mówiący językami niech zamilknie podczas publicznego spotkania Kościoła albo niech chwali Boga prywatnie. Z glosolalią mamy do czynie-

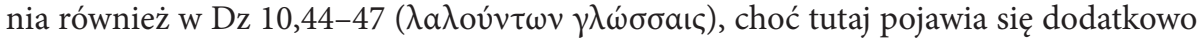
pewna nowość: językami mówią poganie jeszcze nieochrzczeni. Glosolalia jest więc zewnętrznym znakiem ich wiary i przyjścia Ducha, które przygotowują ich do chrztu.

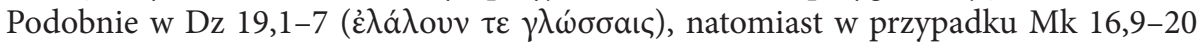

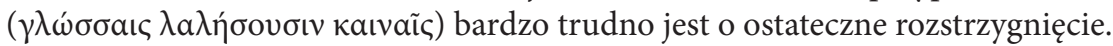

Z kolei w Dz 2, gdzie jest wzmianka o tym, że apostołowie podczas Pięćdziesiątni-

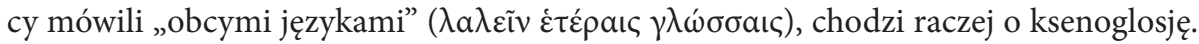

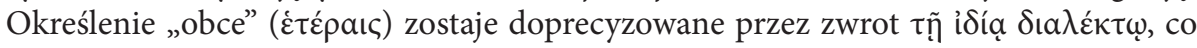
wskazuje na mówienie językami obcymi rzeczywiście istniejącymi i zrozumiałymi.

Brakuje natomiast w tekstach Nowego Testamentu jakiejkolwiek wzmianki o jubilacji takiej, jak ją rozumiał św. Augustyn.

\footnotetext{
Abstract. The article aims to answer the question of whether the gift of tongues in apostolic times, as it was presented in the texts of the New Testament, meant using a foreign language that was actually existing and comprehensible, or prayer in an incomprehensible language. An analysis of respective texts revealed that Acts 2 presents

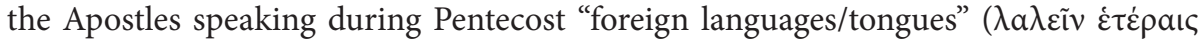

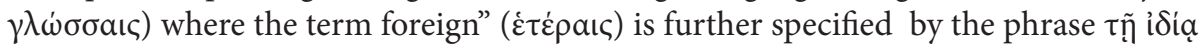


$\delta\llcorner\alpha \lambda \dot{\varepsilon} \kappa \tau \omega$, which indicates speaking in foreign languages that are actually existing and understandable.

Instead, Paul's presentation of the gift of languages in 1 Cor $12-14$, where the

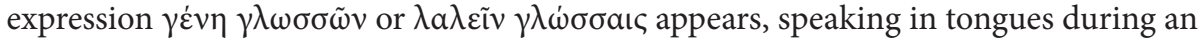
event at the house of Cornelius in Acts 10,44-47 ( $\lambda \alpha \lambda \varepsilon \tilde{\varepsilon} \nu ~ \gamma \lambda \omega \sigma \sigma \sigma a ı)$ ), in Ephesus Acts 19,1-17 $\lambda \alpha \lambda \varepsilon \tilde{\imath} \nu ~ \gamma \lambda \omega \sigma \sigma \alpha ı)$ ) would rather be about speaking in non-existent and incomprehensible languages.

Finally, the analysis of the announcement in Mk 16.9-20 that Jesus' disciples will

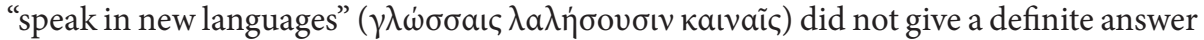
as to whether glossolalia or xenoglossia were involved.

However, there is no mention in the New Testament texts of jubilation as understood by St. Augustine.

Słowa kluczowe: dar języków; Pięćdziesiątnica; glosolalia; ksenoglosja; jubilacja; 1 List do Koryntian; Dzieje Apostolskie; ruch charyzmatyczny.

Keywords: the gift of tongues; the Pentecost; glossolalia; xenoglossy; jubilation; 1 Corinthians; Acts of the Apostles; charismatic movement.

\section{Wstęp}

W naszych czasach odżywa zarówno we wspólnotach zielonoświątkowych, jak i w Kościele katolickim, zwłaszcza we wspólnotach charyzmatycznych katolickiej Odnowy w Duchu Świętym, praktyka modlitwy językami ${ }^{1}$. Fenomen ten jednak, oprócz entuzjazmu ze strony jego zwolenników, wzbudza jednocześnie wiele kontrowersji i dyskusji w Kościele katolickim i poza nim. Pomijając kwestię rozumienia daru języków we wspólnotach zielonoświątkowych ${ }^{2}$, w katolickiej refleksji nad nim dają się zauważyć wyraźnie dwie tendencje. Z jednej strony, liderzy i członkowie wspólnot katolickiej Odnowy w Duchu Świętym lub Szkół Nowej Ewangelizacji utożsamiają ten dar z charyzmatem mówienia językami znanym w Kościele apostolskim ${ }^{3}$. Z drugiej zaś krytycy zjawiska od-

1 Na aktualność zjawiska zwracają uwagę m.in. M. Rosik, Dar języków. Biblia, historia, najpiękniejsze świadectwa, (Serafin) Kraków 2015; A. Siemieniewski, M. Kiwka, Języki zognia. Dar języków w Biblii, historii i we współczesności Kościoła, (Wydawnictwo Wrocławskiej Księgarni Archidiecezjalnej) Wrocław 2017.

2 Zob. np. F.D. Macchia, Tongues and Prophecy, s. 63-69; W.J. Samarin, Tonques of Men and Angels. The Religious Language of Pentecostalism, (Macmillan) New York 1972.

3 Por. F.A. Sullivan, Charyzmaty i Odnowa Charyzmatyczna, s. 109-110. 
rzucają takie rozumienie fenomenu, oskarżając ruch charyzmatyczny w Polsce i na świecie o protestantyzację Kościoła katolickiego, uleganie bezkrytycznym wpływom wspólnot zielonoświątkowym i pentekostalizację wiary katolickiej4. Pomijam tutaj kwestię, czy rzeczywiście ruchy charyzmatyczne w Kościele katolickimi ulegają wpływom zielonoświątkowym i pentekostalizują wiarę katolicką, gdyż jest to temat na odrębne opracowanie. Ważniejszą kwestią jest pytanie, czy praktykowana dzisiaj w Kościele modlitwa językami jest tym samym darem języków z czasów apostolskich czy też nie. O ile zwolennicy utożsamiania dzisiejszego daru języków z charyzmatem znanym już w Kościele apostolskim odwołują się zasadniczo tylko do tekstów Nowego Testamentu, o tyle jego przeciwnicy opierają się zarówno na pismach nowotestamentalnych, jak i tekstach patrystycznych pierwszych wieków. Dobrym tego przykładem są opracowania bpa Andrzeja Siemieniewskiego, który - analizując teksty Ojców Kościoła pierwszych kilku wieków - doszedł do następującej konkluzji:

Opisane w Nowym Testamencie mówienie językami nie było według starożytnych chrześcijan modlitwą w niezrozumiałych dźwiękach pod wpływem duchowego natchnienia, ale posługiwaniem się autentycznym ludzkim językiem w celu zakomunikowania jakiejś treści słuchaczom. Jeśli Biblia wspomina o ich niezrozumiałości (1 Kor 14), to starożytne chrześcijaństwo wyjaśniało, że wynika to z tego, iż język taki mógł być nieznany w konkretnym środowisku: na przykład język tracki w Koryncie albo scytyjski w Rzymie 5 .

Ten sam Autor w innym miejscu precyzuje, że „charyzmatyczną glosolalię nazywaną we współczesnej Odnowie w Duchu Świętym 'modlitwą językami' roztropniej byłoby interpretować jako coś analogicznego do starożytnej jubilacji niż jako odpowiednik mówienia językami w sensie biblijnym"6, gdzie przez jubilację (łac. jubilare - krzyczeć z radości) rozumie on modlitwę głośną, ale całkowicie niezrozumiałą, ponieważ wyrażoną bez sylab tworzących konkretne i zrozumiałe słowa. Autor, moim zdaniem, popełnia metodologiczny błąd, pro-

4 Por. A. Kobyliński, Etyczne aspekty, s. 93-130.

5 Cytat za http://www.siemieniewski.archidiecezja.wroc.pl/?q=node/34 (dostęp: 04.06.2020); por. A. Siemieniewski, Dary duchowe w dawnych wiekach Kościoła. „Nie zaniedbuj w sobie charyzmatu" (1 Tm 4,14) - Czesść VI, Wrocław 2005; A. Siemieniewski, M. Kiwka, Języki z ognia, Wrocław 2017.

6 A. Siemieniewski, Czy Kościót pierwszych wieków znał modlitwę w językach?, w: http://www.apologetyka.katolik.pl (dostęp: 19.02.2020). Ta sama myśl została powtórzona w opracowaniu A. Siemieniewski, M. Kiwka, dz. cyt. 
jektując na teksty Nowego Testamentu interpretację Ojców Kościoła z okresu od II do V wieku. Wiemy, że Ojcowie Kościoła zazwyczaj brali za punkt wyjścia w swojej refleksji nad darem języków opis Pięćdziesiątnicy, natomiast pomijali pozostałe teksty Nowego Testamentu. O ile można się zgodzić, jak zobaczymy dalej, że podczas Pięćdziesiątnicy apostołowie głosili dzieła Boże w obcych, ale rzeczywiście istniejących i zrozumiałych językach, których się wcześniej nie uczyli, o tyle takiego rozumienia nie można rozciągnąć choćby na 1 Kor 12-14 czy inne teksty nowotestamentalne. Kluczowe bowiem dla nas dzisiaj jest nie tyle pytanie o to, jak Ojcowie Kościoła rozumieli dar języków z czasów apostolskich, ile jak był on rozumiany w samych czasach apostolskich. A dostęp do tradycji apostolskiej w tym względzie mamy zasadniczo tylko poprzez odnośne teksty Nowego Testamentu. Pomijając kwestię, czy współczesny dar języków można identyfikować z podobnym charyzmatem z czasów apostolskich, warto z kilku powodów powrócić do próby całościowego przedstawienia rozumienia daru języków w tamtym okresie. Po pierwsze, dlatego że istnieje ciągle w tej materii duże zamieszanie terminologiczne, co prowadzi do używania np. terminu glosolalia zarówno na określenie mówienia językami rzeczywiście istniejącymi, jak też językami niezrozumiałymi. Po drugie, choć patrystyczne rozumienia daru języków jest ważne i czeka nadal na swoje całościowe opracowanie ${ }^{7}$, to jednak nie można wniosków Ojców Kościoła z IV czy V wieku projektować na czasy apostolskie, ale należy próbować odtworzyć rozumienie tego charyzmatu na podstawie tylko Nowego Testamentu. Po trzecie, rekonstrukcja apostolskiego rozumienia daru języków musi opierać się na analizie wszystkich tekstów Nowego Testamentu, które traktują o tym fenomenie. Istnieje wiele opracowań egzegetycznych, które koncentrują się albo tylko na $\mathrm{Dz} 2,1-13^{8}$ albo tylko na 1 Kor $12-14^{9}$, a wnioski tych badań są rozciągane na cały Nowy Testament.

7 Por. przyczynkarskie opracowania patrystycznej interpretacji daru języków - A. Siemieniewski, Dary duchowe $w$ dawnych wiekach Kościoła. „Nie zaniedbuj w sobie charyzmatu" (1 Tm 4,14) - Część VI, Wrocław 2005; M. Rosik, Zaczęli mówić rozmaitymi językami (Dz 2,4), s. 220-228; idem, Pierwszy List do Koryntian, s. 402-412; A. Siemieniewski, M. Kiwka, dz. cyt.

8 Oprócz komentarzy do Dziejów Apostolskich, zazwyczaj bardzo syntetycznych i powierzchownych zob. m.in. Ch. Wolf, $\Lambda \alpha \lambda \varepsilon \tilde{v} v \gamma \lambda \omega \sigma \sigma \alpha \iota \varsigma$ in the Acts of the Apostles, s. 189-201; M. Rosik, Zaczęli mówić rozmaitymi językami (Dz 2,4), s. 215-228; M. Kossowski, Czym jest dar języków?, s. 123-137.

9 Zazwyczaj chodzi o komentarze do 1 Listu do Koryntian - zob. np. A. C. Thiselton, The First Epistle to the Corinthians, s. 970-989; M. Rosik, Pierwszy List do Koryntian, s. $368-395$. 
Można zatem mieć wątpliwości, co do prawdziwości stwierdzenia, że „odpowiedź na pytanie, czy mówienie obcymi językami, znane z opisu Pięćdziesiątnicy, jest tym samym, co charyzmat mówienia językami, występujący w 1 Liście do Koryntian, pozostanie na zawsze crux interpretationis" ${ }^{10}$. W stępna bowiem analiza świadectw nowotestamentalnych prowadzi do hipotezy, że Dz 2 i 1 Kor 12-14 przedstawiają dwa różne dary Ducha Świętego w Kościele apostolskim i nie można ich ze sobą utożsamiać ani redukować jednego do drugiego ${ }^{11}$. Pierwszy tekst dotyczy raczej daru ksenoglosji, natomiast drugi glosolalii, a jubilacja rozumiana jako naturalne okrzyki radości wyrażone sylabami nie pojawia się w ogóle w Nowym Testamencie w kontekście daru języków. Zarówno Paweł, jak i autor Dziejów Apostolskich nigdy nie przedstawiają „mówienia językami” lub „mówienia obcymi językami” jako zjawisk naturalnych, ale zawsze jako przejaw działania Ducha Świętego. Stawiam zatem w niniejszym studium hipotezę badawczą, że teksty Nowego Testamentu potwierdzają, że w czasach apostolskich znane było zarówno zjawisko glosolalii, czyli modlitwy językami niezrozumiałymi, wyrażoną bez sylab tworzących konkretne i zrozumiałe słowa, jak również ksenoglosji, czyli głoszenie Ewangelii językami rzeczywiście istniejącymi i zrozumiałymi dla słuchaczy, chociaż nieznanymi głoszącym. Powyższą hipotezę badawczą będę starał się uzasadnić na podstawie szczegółowej analizy wszystkich tekstów Nowego Testamentu, odwołując się, oczywiście, do istniejących opracowań ${ }^{12}$. Zanim jednak przejdę do analiz odpowiednich tekstów, konieczne jest uporządkowanie terminologii dotyczącej tak zarysowanej problematyki.

10 M. Kossowski, Czym jest dar języków? Studium egzegetyczne Dz 2,1-13, s. 124.

11 Autorzy starszych opracowań, jak J.G. Davies, Pentecost and Glosolalia, s. 228-231; Z.C. Hodges, The Purpose of Tongues, s. 226-233; R.H. Gundry, Ecstatic Utterance, s. 299-307; K. Haacker, Das Pfingstwunder als exegetisches Problem, s. 125-13; G. Hasel, Speaking in Tongues, s. 109-163; przekonują, że Paweł, pisząc o glosolalii w 1 Kor 12-14, miał na myśli mówienie językami rzeczywiście istniejącymi i zrozumiałymi tak jak apostołowie podczas Pięćdziesiątnicy, z kolei np. M. Kossowski, Czym jest dar języków?, s. 125-136 czy C. Forbes, Prophecy and Inspired Speech, s. 47-53 starają się wykazać, moim zadaniem, mało przekonująco, że wspólnota jerozolimska (Dz 2,1-13) podobnie jak koryncka (1 Kor 12-14) posługiwały się tym samym charyzmatem glosolalii rozumianym jako mówienie językiem nieistniejącym i niezrozumiałym dla słuchaczy.

12 Mamy, co prawda, studium V. Scippa, La glossolalia nel Nuovo Testamento. Ricerca esegetica secondo il metodo storico-critico e analitico-strutturale, Napoli 1982 i A. Vanhoye, I carismi nel Nuovo Testamento, Roma 1994, ale pierwsze jest już dosyć przestarzałe, natomiast drugie jest tak naprawdę skryptem dla studentów Biblicum. 


\section{Terminologia}

Jak wspomniałem na wstępie, do opisania daru języków w czasach apostolskich stosuje się często zamiennie różne terminy, takie jak glosolalia lub ksenoglosja czy jubilacja na wyrażenie tych samych rzeczywistości, co tylko potęguje zamieszanie w badaniach. Zatrzymajmy się zatem krótko nad uporządkowaniem terminologicznym. W słynnym słowniku Kopalińskiego glosolalię określa się jako fenomen obecny w niektórych kultach religijnych, który polega na wykrzykiwaniu w stanie ekstazy bezładnych słów i dźwięków uznawanych za głos Boga lub tworzeniu dowolnych zespołów dźwięków bez jakiegoś konkretnego znaczenia ${ }^{13}$. Sam termin "glosolalia” powstał z połączenia czasownika greckiego $\lambda \alpha \lambda \dot{\varepsilon} \omega$ - „mówić” z rzeczownikiem $\gamma \lambda \tilde{\omega} \sigma \sigma \alpha$ - ,język”. W starożytnej Grecji fenomen pojawiał się w obrzędach religijnych, np. ku czci Dionizosa lub Apollina, ale znany był również i Mezopotamii ${ }^{14}$. W Nowym Testamencie zwrot

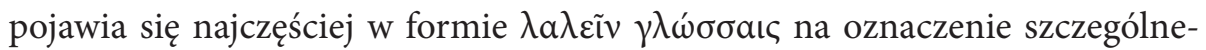
go daru Ducha Świętego. Choć termin glosolalia został użyty po raz pierwszy w XIX wieku przez teologa protestanckiego Frederica Williama Farrara ${ }^{15}$, to jednak dosyć szybko przyjął się również w środowisku chrześcijańskim i do dzisiaj jest powszechnie używany w całym świecie chrześcijańskim na opisanie dary języków ${ }^{16}$. Według Sullivana dzisiejszy dar języków, który praktykują wspólnoty charyzmatyczne byłby takim samym charyzmatem, jak ten opisany choćby w 1 Kor 12-14 i oznaczałby mówienie językiem niezrozumiałym zarówno dla mówiącego jak też dla słuchaczy ${ }^{17}$. Taka glosolalia domaga się towarzyszącego jej daru „wyjaśniania języków”, zwanego też hermeneglosją

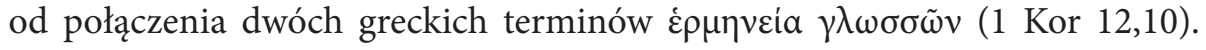
Większość teologów zgadza się, że w 1 Kor 12-14 mamy do czynienia właśnie z glosolalią, czyli mówieniem modlitwą w językach niezrozumiałych, natomiast w przypadku opisu Pięćdziesiątnicy w Dz 2,1-13 zdania są już podzie-

13 Por. W. Kopaliński, Słownik wyrazów obcych, s. 396.

14 Zob. J. Malz, W sprawie daru jezyków, s. 70-71; M. Rosik, Zaczęli mówić rozmaitymi językami (Dz 2,4), s. 215-228.

15 Por. F.W. Farrar, Life and Work of St. Paul, New York 1880.

16 Por. J. Behm, $\gamma \lambda \tilde{\omega} \sigma \sigma \alpha$, s. 719-27; Glossolalia, w: The Oxford English Dictionary, t. 4, Oxford 1970, s. 232; J.M. Ruiz Gonzales, Glossolalia, kol. 1307-1308; G. Dautzenberg, Glossolalie, s. 225-246; D. Sanger, $\gamma \lambda \tilde{\omega} \sigma \sigma \alpha$, s. 1918-1923; R.P. Spittler, Glossolalia, s. 670.

17 Por. F.A. Sullivan, Charyzmaty i Odnowa Charyzmatyczna, s. 109-110. 
lone. Ponieważ w Dz 2,4 nie pojawia się zwrot identyczny jak w 1 Kor 12-14

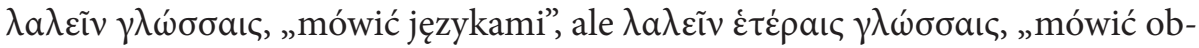
cymi językami”, stąd niektórzy badacze uznają to również za glosolalię ${ }^{18}$, natomiast zdecydowana wiekszość egzegetów widzi tutaj raczej ksenoglosję (od

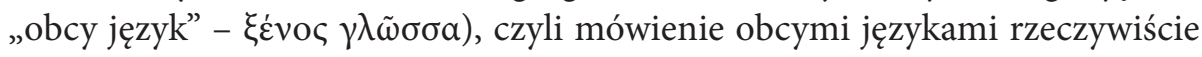
istniejącymi i zrozumiałymi dla innych, których samemu nigdy się wcześniej nie uczyło ${ }^{19}$. Z kolei jubliacja to termin pochodzący od łacińskiego iubilatio i oznacza zupełnie naturalne zjawisko, modlitwę wypowiadaną głośno, ale całkowicie niezrozumiałą, ponieważ wyrażoną bez sylab tworzących konkretne i zrozumiałe słowa, swego rodzaju krzyczenie $\mathrm{z}$ radości ${ }^{20}$. Po raz pierwszy wprowadził go do refleksji teologicznej św. Augustyn ${ }^{21}$, który uważał, że jeśli w czasach apostolskich mówiono o darze języków, to zawsze chodziło o posługiwanie się niewyuczonym i osobiście nieznanym, ale jednak rzeczywistym językiem obcym. Natomiast jubilacja to wydawanie przez człowieka dźwięków, które wyrażają to, czego nie da się wyrazić słowami, to nieskrępowane wyrażanie radości wychodzące poza sferę sylab, wyrazów, języka. W swojej zewnętrznej formy jubilacja jest śpiewem podobnym do świeckich zwyczajów występujących przy żniwach czy przy winobraniu, którego biskup Hippony nie uważał za dar Ducha Świętego i nie widział żadnego związku między modlitwą jubilacji a biblijnym darem mówienia obcymi i niewyuczonymi językami, które miały służyć głoszeniu Ewangelii innym narodom. Tak rozumiana jubilacja i próby jej aplikacji do interpretacji mówienia językami w czasach apostolskich nastręcza jednak bardzo poważne problemy. Po pierwsze, termin ten nie jest biblijny, nie występuje w katalogu charyzmatów przedstawionym przez Pawła ani w żadnym z tekstów Nowego Testamentu traktujących o darze języków. Po drugie, pojawia się ona stosunkowo późno w refleksji teologicznej o charyzmatach, bo dopiero w IV-V wieku i po trzecie, Augustyn, jak zresztą większość Ojców Kościoła, za fundament wszelkiej refleksji teologicznej o charyzmacie mówienia językami brał opis Pięćdziesiątnicy pomijając zupełnie 1 Kor 12-14. Stąd jego wniosek, że dar języków, to zawsze mówienie językiem zrozumiałym dla słuchaczy. Gdyby rzeczywiście tak było, to Paweł nie nakazywałby wyja-

18 M. Kossowski, Czym jest dar języków?, s. 125; C. Forbes, Prophecy and Inspired Speech, s. 47-53.

19 Por. M. Rosik, Zaczeli mówić rozmaitymi językami (Dz 2,4), s. 215.

20 Por. E. Ensley, A Brief History of Jubilation, s. 276-298.

21 Por. Augustyn, De civitate Dei 22,8; Enarrationes in Psalmos Ps 32,8 i Ps 99,4. 
śniać przesłania głoszonego w językach we wspólnocie korynckiej. Wszelka więc próba, patrystyczna czy dzisiejsza, naturalistycznego rozumienia daru języków ignoruje intencje autorów biblijnych i przeczy zasadom interpretacji tekstów. Jeśli chcemy właściwie zrozumieć ten fenomen, musimy się skupić na szczegółowej analizie wszystkich tekstów Nowego Testamentu na ten temat.

Nadzwyczajny fenomen mówienia językami jest wzmiankowany w Nowym Testamencie przez trzech autorów. Św. Paweł poświęca tej tematyce 1 Kor 12-14 $4^{22}$, Łukasz opisuje go w Dz 2,1-13; 10,44-47 i 19,1-7, wreszcie pojawia się on w tzw. drugim zakończeniu Ewangelii Marka 16,17²3. W takiej też kolejności będą one analizowane w niniejszym studium.

\section{Dar języków w 1 Kor 12-14}

Święty Paweł w 1 Liście do Koryntian odnosi się do wielu problemów, które trapiły założoną przez niego wspólnotę uczniów Jezusa w Koryncie. Jedną z takich kwestii było niewątpliwie korzystanie z różnych charyzmatów, które ujawniły się w tej wspólnocie Kościoła wywołując z jednej strony entuzjazm, z drugiej zaś wiele zamieszania. Paweł mierzy się z tematyką charyzmatów w 1 Kor 12,1-14,40²4, gdzie w 12,1-11 podkreśla, iż choć charyzmaty Ducha Świętego mogą być liczne, to jest jeden Duch tak jak liczne są członki a jeden Kościół Chrystusa (12,12-31). W r. 13 przytacza słynny hymn o miłości, która powinna być fundamentem wszelkich charyzmatów i jedności Kościoła, zaś w r. 14 przedstawia zasady korzystania $\mathrm{z}$ charyzmatów. Po wprowadzeniu w początkowych wersetach r. 12 Paweł najpierw podkreśla w 12,7, że „każdemu objawia

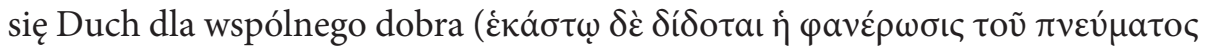

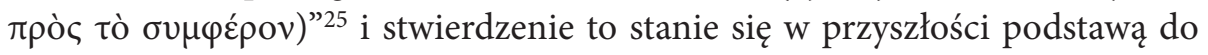

22 Teksty Rz 8,26-27; 2 Kor 12,2-4; 1 Tes 5,19 nie dotyczą tego tematu. Odnośnie do pierwszego tekstu zob. A.J.M. Wedderburn, Romans 8.26-Towards a Theology of Glossolalia?, s. 369-377.

23 Por. V. Scippa, dz. cyt.; A. Vanhoye, I carismi nel Nuovo Testamento, s. 97-110.

24 Tak zazwyczaj całą sekcję dzielą egzegeci - por. R.A. Horlsey, 1 Corinthians, s. 165-196; R.F. Collins, First Corinthians, s. 441-524; A.C. Thiselton, The First Epistle to the Corinthians, s. 970-989; C.S. Keener, 1-2 Corinthians, s. 99-120; J. Fitzmyer, First Corinthians, s. 453-538; Rosik, Pierwszy List do Koryntian, s. 381-384; jedynie P. Perkins, 1 Corinthians, s. 132-170 rozpoczyna sekcję wcześniej, od 11,2.

25 Cytaty z Nowego Testamentu za Biblią Tysiąclecia, Poznań 2014, wyd. V; tekst grecki Barbara et Kurt Aland, Novum Testamentum Graece, Stuttgart $1993^{27}$. 
definicji charyzmatów przez św. Tomasza jako daru „dla dobra/użyteczności innych" (S. Th. III,27,6) i Konstytucję Apostolską Lumen Gentium 7 jako daru „dla dobra/użyteczności Kościoła”. W dalszej części, w. 8-10 Paweł wymienia

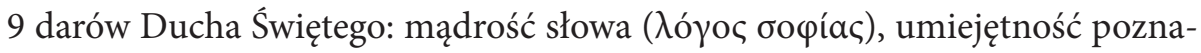

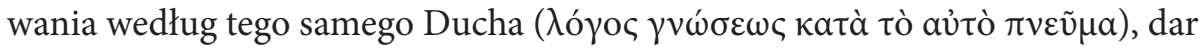

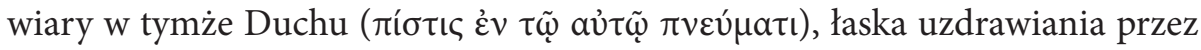

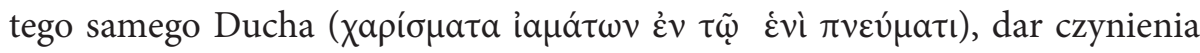

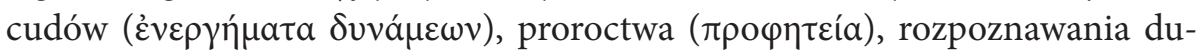

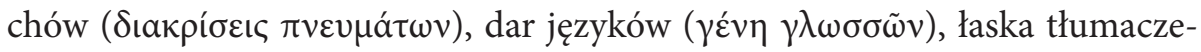
nia języków ( $\varepsilon \rho \mu \eta v \varepsilon i ́ a ~ \gamma \lambda \omega \sigma \sigma \omega \tilde{v})$. Dwa pierwsze i cztery ostatnie charyzmaty dotyczą słowa, natomiast trzy środkowe koncentrują się na działaniu ${ }^{26}$. Nas oczywiście najbardziej interesuje dar języków oddany w j. greckim przez wyrażenie $\gamma \varepsilon ́ v \eta \gamma \lambda \omega \sigma \sigma \tilde{\omega} v$, który dosłownie oznacza „rozmaitości/różne przejawy języków"27. Zauważmy, że nie mamy tutaj jeszcze typowego zwrotu $\lambda \alpha \lambda \varepsilon \tilde{v} v$

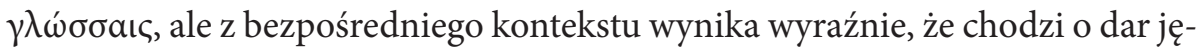
zyków. Jak rozumieć zwrot $\gamma \varepsilon ́ v \eta \eta \lambda \omega \sigma \sigma \tilde{\omega} v$ ? Chodzi o język obcy, ale istniejący i zrozumiały przynajmniej dla niektórych słuchaczy czy raczej niezrozumiały dla otoczenia? Niektórzy badacze nie rozstrzygają tej kwestii sugerując, że dar języków to rodzaj modlitwy, który polega na zwracaniu się do Boga za pomocą dźwięków stanowiących rzeczywisty język bądź są spontanicznym sposobem mówienia, niezrozumiałym dla słuchaczy. Ta druga forma, gdy jest stosowana publicznie, domaga się daru tłumaczenia ${ }^{28}$. Sądzę jednak, że znowu kontekst wskazuje wyraźnie, że chrześcijanie posiadający ten dar przemawiali językiem niezrozumiałym dla otoczenia dlatego, że Paweł łączy go właśnie z darem wy-

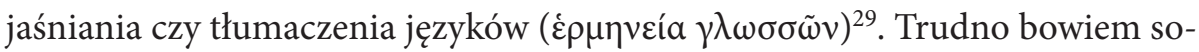
bie wyobrazić, żeby tłumaczono język obcy, rzeczywiście istniejący, gdyby ktoś

26 Por. Nardoni, The Concept of Charism in Paul, s. 68-80; Fung, Ministry, Community and Spiritual Gifts, s. 3-20; Harrington, Charism and Ministry, s. 245-257; Radziwiołek, Dary Ducha Świętego w życiu chrześcijanina. Studium biblijne na podstawie Corpus Paulinum, Legnica 2006.

27 Por. szczegółową analizę tych terminów przez A.C. Thiselton, The First Epistle to the Corinthians: a Commentary on the Greek Text, s. 974-982.

28 Por. Thiselton, The First Epistle to the Corinthians, s. 974-982; Rosik, Pierwszy List do Koryntian, s. 400-401; Malz, W sprawie daru języków, s. 17-21; Horlsey, 1 Corinthians, s. 169-171; Perkins, 1 Corinthians, s. 146-149.

29 Por. Dąbrowski, Lisy do Koryntian, s. 243; Orr -Walther, 1 Corinthians, s. 277-278; Rosik, Pierwszy List do Koryntian, s. 395. 
w nim przemawiał pod wpływem Ducha Świętego. Tak naprawdę nie chodzi o tłumaczenie w sensie przekładu z jednego języka obcego na drugi, ale o wyjaśnienie, na co wskazuje użyty termin $\dot{\varepsilon} \rho \eta \eta v \varepsilon^{3} \alpha^{30}$. To potwierdzałoby również, że nie mamy tutaj do czynienia z językiem obcym rzeczywiście istniejącym, bo w takim przypadku wystarczyłoby proste tłumaczenie filologiczne bez wyjaśnień. Według św. Pawła, kryterium korzystania z dary języków jest budowanie wspólnoty, czyli powinno się korzystać z niego wtedy, gdy po wypowiedzeniu przesłania w językach pojawi się jego wyjaśnienie ${ }^{31}$.

Pod koniec tego rozdziału, kiedy Paweł wymienia ponownie różne charyzmaty mówiąc o różnych zadaniach w Kościele, $\mathrm{w} 12,28$ pojawia się po raz

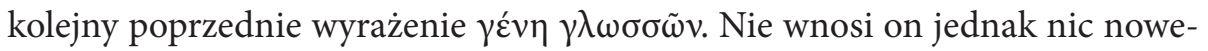
go do rozumienia dary języków. Apostoł jedynie zachęca do przyjęcia różnorodności charyzmatów w Kościele i unikania pysznego wywyższania się jednych nad drugimi z powodu ich otrzymania. Ciekawy jest natomiast pod tym względem fragment z 12,30. Paweł pyta retorycznie czy wszyscy mają moc czy-

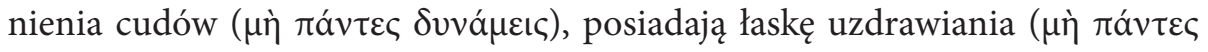

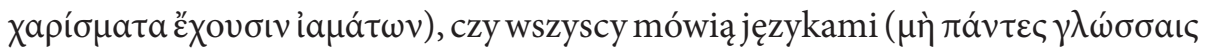

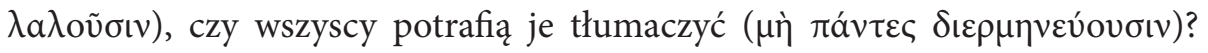
Jak widać, w przypadku daru języków Paweł nie powtarza tutaj poprzedniego

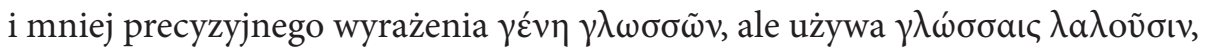
który, jak zobaczymy w r. 14, stanie się swego rodzaju zwrotem technicznym na wyrażanie daru mówienia językami. Ponieważ znowu ten dar pojawia się wraz z następującym zawsze po nim charyzmacie wyjaśniania, należy przypuszczać, że chodzi o mówienie językami nieistniejącymi i niezrozumiałymi dla słucha-

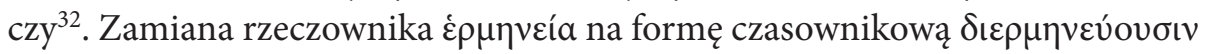
nic tutaj nie zmienia, bo i tak chodzi o wyjaśnienie (łac. interpretatio), a nie zwykłe, filologiczne tłumaczenie (łac. translatio). W 13,1, który, jak pamiętamy, jest wprowadzeniem do słynnego hymnu o miłości, występuje fraza taĩ

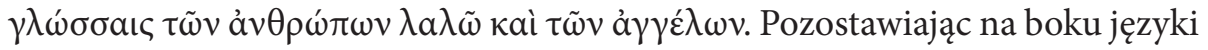

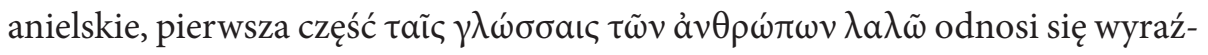

30 Por. Thiselton, The First Epistle to the Corinthians, s. 974-982; Rosik, Pierwszy List do Koryntian, s. 400-401.

31 Por. K. Stendahl, Glosolalia - The New Testament Evidence, s. 110-115.

32 Por. W. Schrage, Der erste Brief an die Korinther, s. 405-413; A. Lindemann, Der Erste Korintherbrief, s. 307-311. 
nie do języka ludzkiego znanego i rzeczywiście istniejącego ${ }^{33}$. Widzimy więc, że

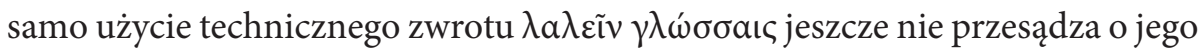
rozumieniu, gdyż Paweł odnosi go zarówno do języków obcych rzeczywiście istniejących i zrozumiałych dla słuchaczy, jak też do języków niezrozumiałych, które wymagają interpretacji lub wyjaśnienia. Kontekst użycia zwrotu decyduje o jego znaczeniu. To pokazuje, jak musimy być bardzo uważni i ostrożni w interpretacji zwrotów użytych przez autorów biblijnych, gdyż ten sam użyty $\mathrm{w}$ różnych kontekstach może mieć różne znaczenie.

Z kolei w 1 Kor 14,1-40 Paweł podaje zasady używania różnych charyzmatów, w tym również daru języków. Zaraz na początku zachęca, aby Koryntianie starali się posiąść miłość i troszczyli się o dary duchowe, zwłaszcza o dar proroctwa, który Apostoł zdaje się stawiać najwyżej. W całej sekcji 14,1-15 Paweł przedstawia cztery elementy charakteryzujące mówienie językami: jest to osobista modlitwa do Boga (w. 2), jest jak nieodróżnialny dźwięk fletu albo harfy (w. 7), jest to modlitwa w duchu, ale bez zaangażowania umysłu (w. 14-15) i zewnętrznym słuchaczom wydaje się szaleństwem (w. 23) ${ }^{34}$. Dalej, w 14,2-4 uzasadnia swoje przekonanie o wyższości daru proroctwa nad darem języków: „Ten bowiem, kto mówi językami, nie ludziom mówi, lecz Bogu. Nikt go nie sły-

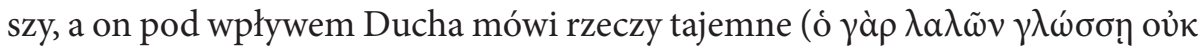

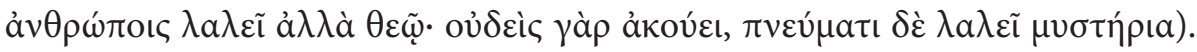
Ten zaś, kto prorokuje, mówi ku zbudowaniu ludzi, ku ich pokrzepieniu

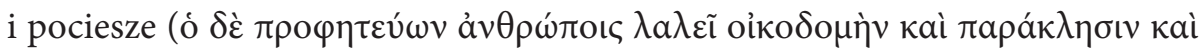

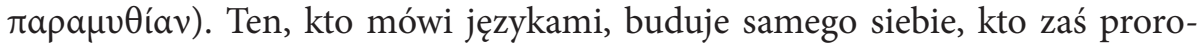

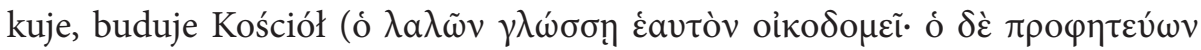

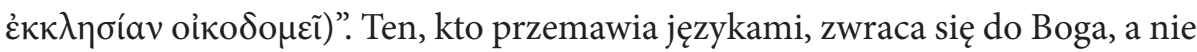
do ludzi. Nikt go nie słyszy w takim sensie, że nikt go nie rozumie, gdyż pod wpływem Ducha wypowiada tajemnice Boga. Już samo to stwierdzenie Pawła wystarczy do wyciągnięcia wniosku, że używane przez niego tutaj określenie

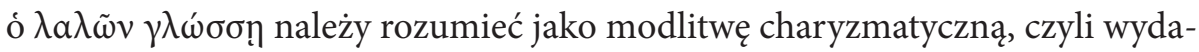
wanie dźwięków, które nie stanowią jakiegoś znanego i możliwego do identy-

33 Choć egzegeci zastanawiają się, czy chodzi tutaj o glosolalię czy też o ksenoglosję lub heteroglosję - por. Rosik, Pierwszy List do Koryntian, s. 428.

34 Por. Horlsey, 1 Corinthians, s. 180; H. Heckel, Paulus und die Charismatiker, s. 117-138; Macchia, Tongues and Prophecy, s. 63-69. 
fikacji języka ${ }^{35}$. Człowiek bowiem korzystający z tego daru mówi nie ludziom i nie oczekuje od nich zrozumienia tego, co mówi, ale Bogu. Jeśli zaś wypowiada tajemnice Boże, potrzebny jest ktoś do ich wyjaśnienia. Takie rozumienie wzmacnia dalsza część powyższego fragmentu, gdzie Paweł odwołuje się do kryterium duchowego budowania siebie darem języków (o $\lambda \alpha \lambda \tilde{\omega} v \gamma \lambda \hat{} \omega \sigma \sigma \emptyset \eta$

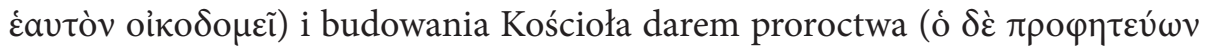

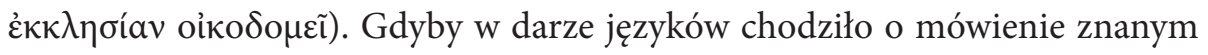
i rzeczywiście istniejącym językiem obcym, wtedy taki dar budowałby duchowo również innych, a ponieważ chodzi o język niezrozumiały, mówiący nim chwali Boga i buduje tylko siebie. Ze względu na mniejszą użyteczność w duchowym budowaniu wspólnoty Paweł stawia dar języków niżej niż proroctwo. Apostoł uznaje więc potrzebę i daru języków i daru proroctwa, chce, aby wszyscy mówili językami, ale jeszcze bardziej, by wszyscy prorokowali (w. $5 \theta \varepsilon \dot{\lambda} \omega \delta \dot{\varepsilon} \pi a ́ v \tau a \varsigma$

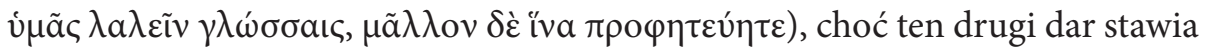
zdecydowanie wyżej jako bardziej użyteczny w budowaniu wspólnoty Kościoła

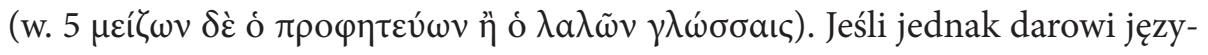
ków towarzyszyć będzie wyjaśnienie, „aby wyszło to na zbudowanie Kościoło-

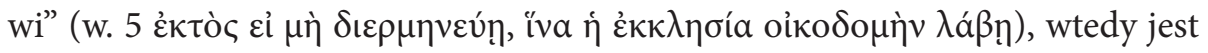
on równy proroctwu. $\mathrm{W}$ w. 6 Paweł kontynuuje swoją argumentację o bezużyteczności daru mówienia językami ( $\gamma \lambda \omega \sigma \sigma \sigma \alpha ı \varsigma ~ \lambda \alpha \lambda \tilde{\omega} v)$ dla wspólnoty, jeśli nie ma nikogo do jego wyjaśnienia, co znowu potwierdza, iż przez ten zwrot Apostoł rozumiał w tym kontekście mówienie językiem niezrozumiałym. Jeszcze dosadniej wyraził to w w. 9 „Tak też i wy, jeśli pod wpływem języków nie wypo-

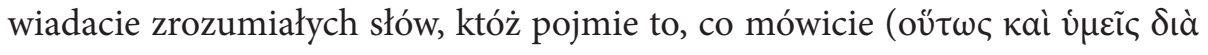

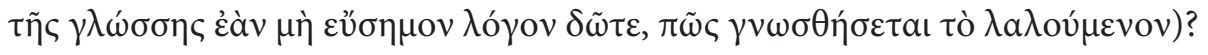

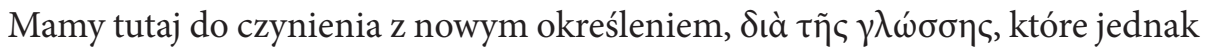
wskazuje wyraźnie, tak jak to zostało przetłumaczone na j. polski, na „mówienie pod wpływem/z powodu języków”. Z perspektywy naszej refleksji ważniejsze jest jednak stwierdzenie, że chodzi o wypowiadanie niezrozumiałych słów

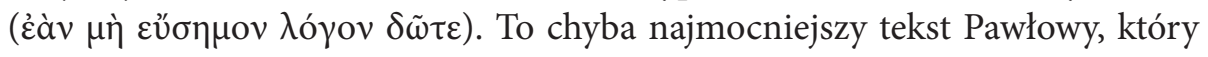
potwierdza, że w darze języków nie chodzi o wypowiadanie słów zrozumia-

35 Por. Davis, Pentecost and Glossolalia, s. 228-231; Currie, Speaking of the Tongues, s. 274-294; Dąbrowski, Lisy do Koryntian, s. 263; Horlsey, 1 Corinthians, s. 195-196; Collins, First Corinthians, s. 478-489; Thiselton, The First Epistle to the Corinthianst, s. 985-988; Keener, 1-2 Corinthians, s. 115-117; Fitzmyer, First Corinthians, s. 476-82; Rosik, Pierwszy List do Koryntian, s. 444-461; Perkins, 1 Corinthians, s. 156-159. 
łych po ludzku, czyli w języku obcym, rzeczywiście istniejącym, ale właśnie niezrozumiałych słów. Jeśli sam Paweł jasno i wyraźnie stwierdza, że mówienie językami oznacza mówienie niezrozumiałych słów, to można się tylko dziwić uporowi niektórych teologów, którzy nie chcą tego przyjąć.

Ostatni aspekt dotyczy modlitwy językami, która jest modlitwą duchem a nie umysłem. W 1 Kor 14,13 Paweł wyjaśnia: „Jeśli więc ktoś korzysta z daru języków (ó $\lambda a \lambda \tilde{\omega} \nu \gamma \lambda \hat{\prime} \sigma \sigma \eta !)$, niech się modli, aby potrafił to wyjaśnić

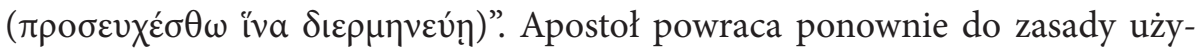
teczności daru języków dla wspólnoty. Mówienie językami we wspólnocie ma sens tylko wtedy, gdy służy jej zbudowaniu, a to ma miejsce wówczas, gdy dar języków występuję łącznie $\mathrm{z}$ darem wyjaśniania przez kogoś innego albo przez samego mówiącego. Dlatego zachęca, aby ten, kto modli się językami sam pro-

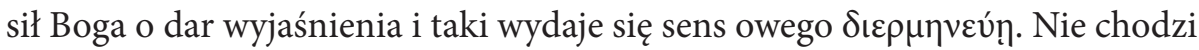
tutaj jednak o analizę lingwistyczną samego języka, ale o charyzmatyczny dar wyjaśnienia przesłania przekazanego przez mówiącego językami niezrozumiałymi dla słuchaczy. Chodzi o dar zrozumienia orędzia i przekazania go wspólnocie $^{36}$. W kolejnym wersecie 14,14 precyzuje, że jeśli "modlę się pod wpływem

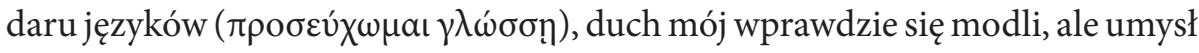
nie odnosi żadnych korzyści”. Stwierdzenie, iż umysł osoby mówiącej językami nie odnosi korzyści, nie oznacza, że umysł jest całkowicie wyłączony, zaś osoba jest w stanie jakiegoś transu albo ekstazy. Scippa twierdzi, że glosolalia jest rodzajem ekstazy, ponieważ w jej trakcie dominuje w człowieku działanie Ducha, natomiast zawieszone jest działanie umysłu ${ }^{37}$. Jego zdaniem Paweł w 1 Kor 14,23, opisując mówienie w językach, porównuje je do szaleństwa, zaś podczas Pięćdziesiątnicy apostołowie są określani jako ci, którzy upili się młodym winem. Zewnętrzne objawy podobne do szaleństwa lub pijaństwa wskazują na to, że chodzi tutaj o ekstazę. Vanhoye słusznie krytykuje takie rozumowanie. Jeśli w Dz 2,13 jest powiedziane, że Piotr jako jeden z tych, którzy mówili obcymi językami, reaguje na to, co mówią ludzie, świadkowie tego wydarzenia, to znaczy, że nie był w stanie ekstazy, kiedy to człowiek nie słyszy tego, co się wokół niego mówi. Jeśli Paweł w 1 Kor 14,23 zakłada hipotetycznie, że wszyscy razem

36 Por. Dąbrowski, Lisy do Koryntian, s. 266-267; Thiselton, The First Epistle to the Corinthians, s. 997-998; Keener, 1-2 Corinthians, s. 118-119; Fitzmyer, First Corinthians, s. 484-486; Horlsey, 1 Corinthians, s. 185-189; Rosik, Pierwszy List do Koryntian, s. 381-384; Perkins, 1 Corinthians, s. 169-170.

37 Por. Scippa, La glossolalia, s. 44.200. 
mówiliby językami wymawiając niezrozumiałe słowa, dałoby to wrażenie szaleństwa, ale wcale nie zakładałoby w sposób konieczny jakiejś zbiorowej ekstazy. Zresztą sam fakt, że Paweł ustala reguły posługiwania się glosolalią w Koryncie zakłada, że nie chodzi tutaj o ekstazę, ale o stan, w którym człowiek nie traci własnej świadomości ani panowania nad sobą. Inaczej jakiekolwiek reguły nie miałby najmniejszego sensu. Nie jest to oczywiście stan zwyczajny, ale doświadczenie natchnienia Bożego, jednak niemożliwe do utożsamienia z ekstazą. Sam św. Paweł wyraźnie odróżnia właśnie charyzmaty, czyli stany natchnienia Bożego, które opisuje w 1 Kor 12-14, od ekstazy, której sam doświadczył i opisał w 2 Kor 12,1-4. Słownictwo w obydwu tekstach jest całkowicie inne, podczas ekstazy nie mówi się, a słyszy rzeczy niewypowiedziane. Ekstaza to stan „porwania” przez Boga i sam Paweł uznaje go za wyjątkowy, podczas gdy dar języków postrzega jako częste doświadczenie chrześcijan w Koryncie ${ }^{38}$. Dalej, Paweł podkreśla, że choć dzięki Bogu mówi językami lepiej od wszystkich Koryntian $(14,18)$ i użyty ten sam zwrot $\gamma \lambda \omega ́ \sigma \sigma \alpha ı \varsigma \lambda \alpha \lambda \tilde{\omega}$ wskazuje wyraźnie, że nie chodzi o znajomość języków obcych, rzeczywiście istniejących i zrozumiałych dla ludzi, ale o języki niezrozumiałe. W Kościele, czyli wspólnocie wierzących, dodaje Apostoł, woli powiedzieć „pięć słów według mojego umysłu/rozeznania, by pouczyć innych, zamiast dziesięć tysięcy wyrazów według daru języków

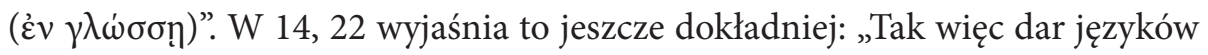
(ai $\gamma \lambda \tilde{\omega} \sigma \sigma \alpha \iota)$ jest znakiem nie dla wierzących, lecz dla pogan, proroctwo zaś nie dla pogan, lecz dla wierzących”. Mamy tutaj wyrażone bardzo wyraźne przekonanie Pawła o tym, że dar języków jest znakiem obecności i działania Boga danym dla ewangelizacji pogan, a nie dla już wierzących chrześcijan. Gdyby bowiem jakiś prosty człowiek lub poganin wszedł na spotkanie Kościoła i wszyscy korzystaliby z daru języków, pomyślałby, że oszaleli (14,23). W 14,26 powraca więc Apostoł do zasady budowania wspólnoty: wszystkie charyzmaty w Kościele, w tym również dar języków ( $\gamma \lambda \tilde{\omega} \sigma \sigma \alpha \nu)$ albo wyjaśniania (غ $\rho \mu \eta v \varepsilon i ́ a v)$

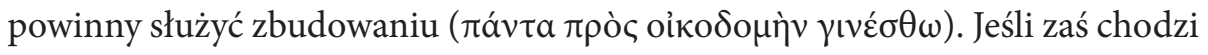

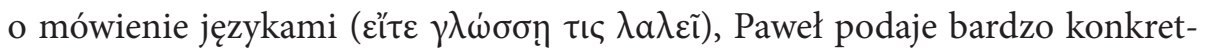
ną i praktyczną regułę (14,27-28): „niech mówią kolejno dwaj, najwyżej trzej,

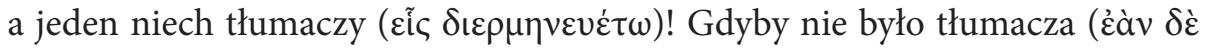

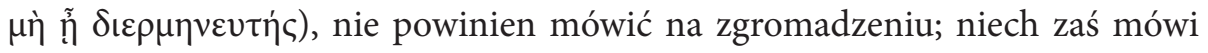
sobie samemu i Bogu!" Widzimy, że powraca tutaj to samo słownictwo na wy-

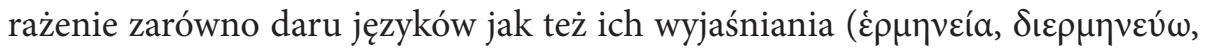

38 Por. Vanhoye, I carismi, s. 98-99. 
$\delta เ \varepsilon \rho \mu \eta v \varepsilon v \tau \eta ́()$. Swoją refleksję Paweł kończy optymistyczną zachętą skierowaną do Koryntian i całego przyszłego Kościoła: „troszczcie się o łaskę prorokowania

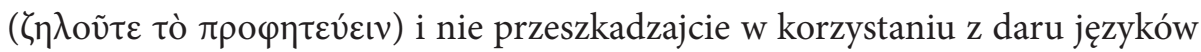

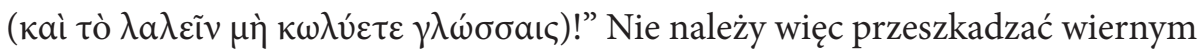
w korzystaniu z charyzmatycznego daru mówienia językami, jeśli służy on budowaniu Kościoła, czyli wtedy, gdy obok mówiącego językami jest ktoś, kto wyjaśnia głoszone orędzie. Jeśli nie ma nikogo do wyjaśnienia, osoby posiadające dar języków powinny raczej milczeć podczas spotkań wspólnoty Kościoła, ale nie należy im zabraniać modlić się indywidualnie językami i chwalić w ten sposób Boga.

\section{Dar języków w Dziejach Apostolskich}

\subsection{Dar języków w dniu Pięćdziesiątnicy (Dz 2,1-11).}

Jak wiemy, księga Dziejów Apostolskich rozpoczyna się narracją o Wniebowstąpieniu Jezusa, ale zanim to nastąpiło zapowiada On swoim uczniom „wy wkrótce zostaniecie ochrzczeni Duchem Świętym” $(1,5)$. W rozdziale 2 znajdujemy relację o Zesłaniu Ducha Świętego na apostołów, który zewnętrznie jest dosyć podobny do 1 Kor 12: mówienie językami jest darem Ducha Świętego i ujawnia się on zewnętrznie w sposób bardzo spektakularny. W 2,4 czytamy: „I wszyscy zostali napełnieni Duchem Świętym, i zaczęli mówić obcymi języ-

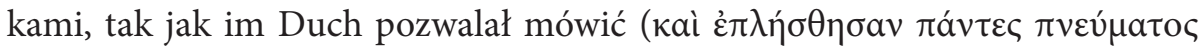

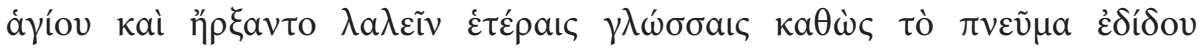

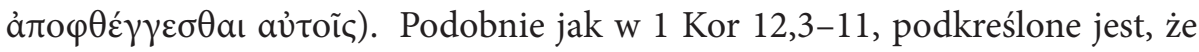

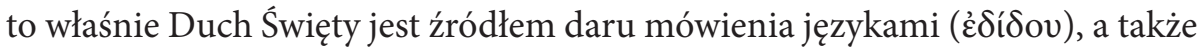

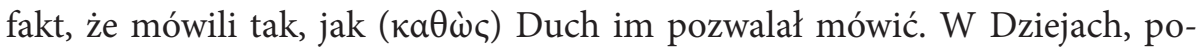
przez związek z zapowiedzią z 1,4 o chrzcie w Duchu Świętym zostaje wyraźnie podkreślone, że mówienie językami jest znakiem, że ten chrzest właśnie teraz się dokonuje ${ }^{39}$. Dla Pawła znakiem chrztu w jednym Duchu jest zebranie się różnych członków w jedno ciało (1 Kor 12,13). Piotr w swojej mowie odrzuca interpretację upicia się, ale wyjaśnia wydarzenie jako spełnienie się proroctw Joela 2, 17-18. Od dawna egzegeci zastanawiają się, czy w Dziejach 2 mamy do czynienia z glosolalią czy ksenoglosją. Kluczowy dla naszych rozważań jest

39 Por. K. Stendahl, Glosolalia - The New Testament Evidence, s. 116-121. 


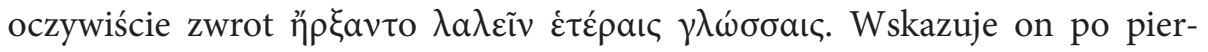
wsze, że wszyscy uczniowie Jezusa zaczęli mówić nie jednym językiem obcym, ale każdy z nich zaczął mówić w innym, obcym języku, tak że wszyscy razem mówili jednocześnie wieloma jezykami obcymi, na co wskazuje wyraźnie lic-

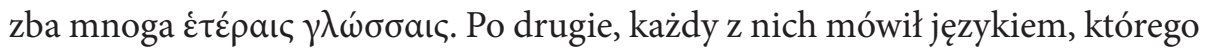
nigdy się nie uczył i którego znajomości nie posiadł drogą naturalnej nauki. Po trzecie, język ten był zrozumiały przez świadków tego wydarzenia, którzy go znali, i po czwarte, był to realnie istniejący język, a nie niezrozumiałe dźwięki ${ }^{40}$. Zwłaszcza ten ostatni element jest bardzo ważny, gdyż sugeruje, że Dz 2 i 1 Kor 12-14 przedstawiają dwa różne fenomeny. Podczas gdy Paweł używa określenia

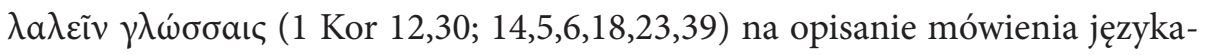
mi nieistniejącymi i niezrozumiałymi, które domagają się wyjaśnienia, Łukasz

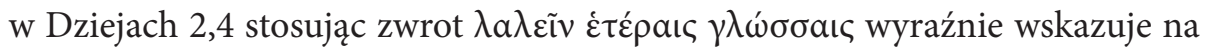
język rzeczywisty i zrozumiały. Na taką interpretację Dz 2,4 wskazuje użycie czasownika greckiego ảं $\varphi \theta \dot{\varepsilon} \gamma \gamma \varepsilon \sigma \theta a$, który w LXX używany był na wyrażenie prorokowania (por. Ez 13,9; Mi 5,12; 1 Krn 25,1) i w Dz 2,14 określa mowę Piotra. Dalej precyzuje, że przebywali wtedy w Jerozolimie pobożni Żydzi ze wszystkich narodów pod słońcem. Oni to usłyszawszy szum, zbiegli się tłumnie i zdumieli, „bo każdy słyszał, jak [tamci] przemawiali w jego własnym języku

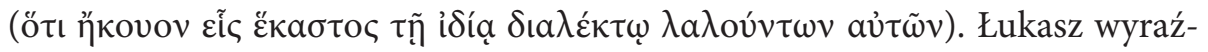
nie daje więc do zrozumienia, że słuchacze słyszeli apostołów przemawiających w ich własnym dialekcie, czyli języku istniejącym i zrozumiałym dla tych, którzy go znali ${ }^{41}$. Podkreślmy więc bardzo mocno, że nie chodziło tutaj o glosolalię taką, jak ją opisał św. Paweł w 1 Kor 12-14. Prywatna modlitwa językami obcymi, o jakiej mowa w 1 Kor 12-14, nie miałaby przecież najmniejszego sensu i Paweł nie łączy glosolalii z głoszeniem Ewangelii po całym świecie, ale widzi ją raczej jako przeszkodę w misji głoszenia nauki Chrystusa poganom (1 Kor 14,21-23). Niektórzy badacze przypuszczają, że étépaıৎ nie należało pierwotnie do tekstu i Łukasz dodałby termin w celu zmiany glosolali w ksenoglosję $e^{42}$, ale wiele wskazuje na to, że już tradycja przedłukaszowa zawierała pełny zwrot

40 Por. M. Rosik, Zaczęli mówić rozmaitymi językami (Dz 2,4), s. 219-220; C. Wolff, $\Lambda \alpha \lambda \varepsilon \tilde{\nu} v \gamma \lambda \omega \sigma \sigma \alpha \iota \varsigma$ in the Acts of the Apostles, s. 189-202. C. Forbes, Prophecy and Inspired Speech, s. 47-53 argumentuje, zresztą mało przekonująco, że zarówno w 1 Kor 12-14 jak też Dz 2 mamy do czynienia z glosolalią.

41 Por. Dąbrowski, Dzieje Apostolskie, s. 236-237; Munck, The Actes of the Apostles, s. $14-15$.

42 Weiser, Die Apostelgeschichte, s. 81; Pesch, Die Apostelgeschichte, s. 99. 


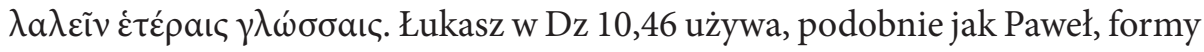

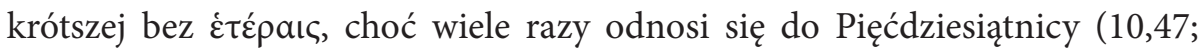
$11,15.17 ; 15,7-8)$. Zwrot $\lambda \alpha \lambda \varepsilon \tilde{v} v \gamma \lambda \omega ́ \sigma \sigma \alpha$ jest mniej precyzyjny i nie jest starszą

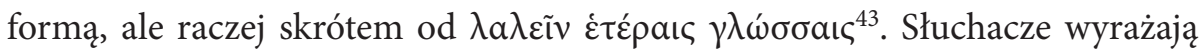
zdziwienie, że apostołowie są Galilejczykami, ,a każdy z nas słyszy swój wła-

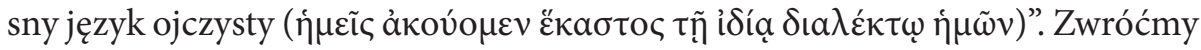
uwagę, że w samej narracji o Pięćdziesiątnicy dwa razy powtórzone jest wyra-

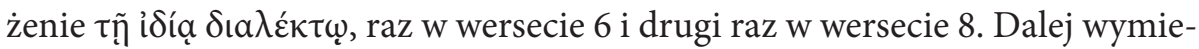
nione są konkretne grupy etniczne, w których słyszy się głoszenie dzieł Bożych: Partowie, Medowie, Elamici, mieszkańcy Mezopotami, Judei, Kapadocji, Pontu, Azji, Frygii, Pamfilii, Egiptu, Lybii, Rzymu, Kreteńczycy i Arabowie. Nie ma wątpliwości, że chodzi tutaj o konkretne istniejące i zrozumiałe języki. Słuchacze podkreślają: „słyszymy ich głoszących w naszych językach wielkie są dzieła

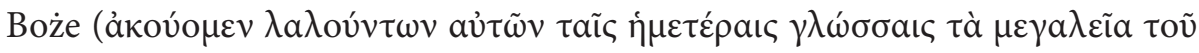

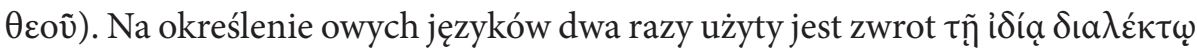

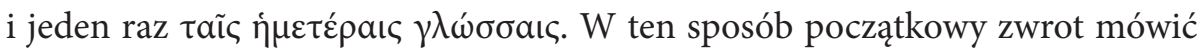

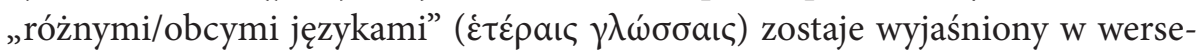

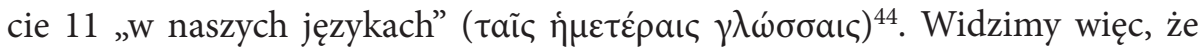
w Dz 2 chodzi o mówienie w językach innych, obcych, których apostołowie wcześniej nie znali, ale o języki istniejące i łatwe do identyfikacji; po drugie, ten cud ma wyraźny cel apostolski przygotowania słuchaczy na przepowiadanie Piotra i uwierzenie. Bardzo konkretne i specyficzne rozumienie zwrotu $\lambda \alpha \lambda \varepsilon \tilde{\varepsilon} v$

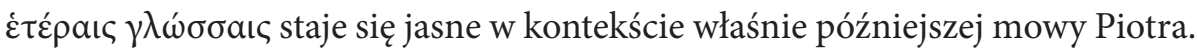
W 1 Kor 14 natomiast glosolalia jest językiem niezrozumiałym, który nie ma żadnej skuteczności apostolskiej $(14,23)$ ani wspólnotowej $(14,4)$, ale jest darem, który służy tylko mówiącemu językiem. Podczas gdy Paweł odróżnia bardzo wyraźnie proroctwo od glosolalii, w Dziejach sam dar mówienia obcymi językami jest przedstawiony jako swego rodzaju proroctwo i Piotr wyjaśni ten fenomen jako realizację proroctwa Joela. Ta zupełnie inna perspektywa w Dz 2 nie oznacza jednak, że tak, jak chcieli Ojcowie Kościoła, a za nimi św. Tomasz (S. Th. II-II, q. 176, a. 1), mamy tutaj do czynienia $\mathrm{z}$ darem stałym udzielonym apostołom do przepowiadania w nowych językach. Kiedy wczytamy się dokładnie w tekst Dz 2, to zauważymy, że nie mówi on nic ani o głoszeniu Ewangelii ani o darze stałym mówienia w obcych językach. Co ciekawe, apostołowie

\footnotetext{
43 C. Wolff, $\Lambda \alpha \lambda \varepsilon \tilde{\varepsilon} v \gamma \lambda \omega \sigma \sigma \alpha \iota \varsigma$ in the Acts of the Apostles, s. 193.

44 Por. Vanhoye, I carismi, s. 100-101.
} 
wcale nie zwracają się z przepowiadaniem do innych ludzi, ale sami w nowych językach wychwalają Boga, a ludzie przychodzą dopiero później. Interpretacja patrystyczna, że apostołowie otrzymali stały dar mówienia obcymi językami w celu przepowiadania Ewangelii całemu światu, jest mocno naciągana i zupełnie rozmija się z intencją autora natchnionego. Dar języków został udzielony po to, aby apostołowie wychwalali wielkie dzieła Boże $(2,11)$, zaś przepowiada później tylko sam Piotr. Ponieważ dar języków został udzielony nie do przepowiadania, ale do oddania chwały Bogu, w tym sensie jest on podobny do glosolalii opisanej w 1 Kor $14 \mathrm{z}$ tą jednak różnicą, że tutaj słuchacze rozumieją języki. Dalej, Łukasz nie wspomina ani słowem o tym, że chodzi tutaj o stałą znajomość wszystkich języków przez apostołów. Tekst podkreśla charakter wyjątkowy tego wydarzenia, które nigdy już nie powtarza się za życia apostołów ani w dziejach Kościoła ${ }^{45}$.

W starożytności proponowano jeszcze inną interpretację, której cudowność miała polegać nie na mówieniu, ale na usłyszeniu, na tzw. cudzie uszu. Według niej apostołowie chwalili Boga w swoim, znanym im języku, czyli zapewne aramejskim, natomiast cud polegał na tym, że poszczególne ludy słyszały każdy swój język. Z kolei starsi badacze proponowali wyjaśnienie, według którego apostołowie chwalili Boga glosolalią, wydając dźwięki, które nie przypominały żadnego rzeczywistego języka, a jedynie słuchacze w cudowny sposób słyszeli swoje języki ${ }^{46}$. Wszystkie te propozycje nie uwzględniają jednak w wystarczający sposób dynamiki samego tekstu, w którym wyraźnie jest powiedziane, że apostołowie głosili w innych językach wielkie dzieła Boże. Dla nas ważne jest natomiast stwierdzenie, że dar opisany w Dz 2 dotyczył mówienia językami obcymi rzeczywiście istniejącymi i był innym darem niż glosolalia, o której pisał Paweł w 1 Kor 12-14.

\subsection{Dz 10,44-47 - dar języków w domu Korneliusza}

Kolejna wzmianka na temat daru języków pojawia się w Dz 10,44-47. Gdy Piotr głosił Ewangelię w domu Korneliusza: „Duch Święty zstąpił na wszystkich, którzy słuchali nauki. I zdumieli się wierni pochodzenia żydowskiego, którzy przybyli z Piotrem, że dar Ducha Świętego wylany został także na pogan.

45 Weiser, Die Apostelgeschichte, s. 85; Pesch, Die Apostelgeschichte, s. 104; C. Wolff, $\Lambda \alpha \lambda \varepsilon \tilde{\varepsilon} v \gamma \lambda \omega \sigma \sigma \alpha \iota$ in the Acts of the Apostles, s. 198-199.

46 Por. Lyonnet, De glossolalia, s. 65-75. 


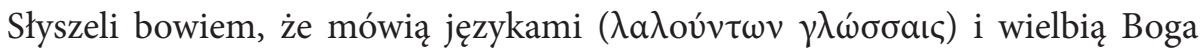
( $\mu \varepsilon \gamma \alpha \lambda v v o ́ v \tau \omega \nu$ tòv $\theta \varepsilon o ́ v)$ ". W tym przypadku mówienie językami jest postrzegane jako działanie Ducha Świętego i, co bardzo ważne dla młodego Kościoła, przyjęcie pogan do wspólnoty chrześcijańskiej. Piotr wykorzystuje ten fakt, aby udzielić chrztu Korneliuszowi i jego rodzinie (10,47), a potem na tej podstawie obronić się przed obiekcjami judeo-chrześcijan $(11,15-17)$ i przywołać ten argument na Soborze w Jerozolimie, domagając się otwarcia Kościoła na pogan (15,7-9). W tekście akcentuje się bardziej zstąpienie Ducha Świętego na pogan niż dar języków, który jest zewnętrznym znakiem rozpoznaw-

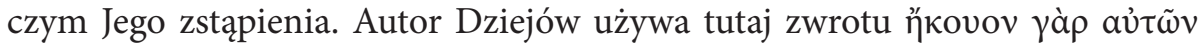

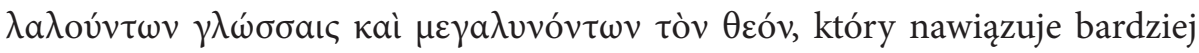

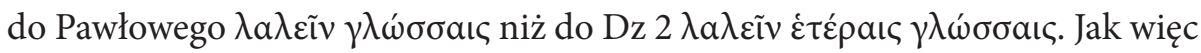
rozumieć $\lambda \alpha \lambda \varepsilon i v \nu ~ \gamma \lambda \omega ́ \sigma \sigma \alpha ı \varsigma \mathrm{w}$ tym kontekście? Chodzi o glosolalię czy raczej o ksenoglosję ? Towarzysze Piotra nie byliby w stanie określić, jakimi obcymi językami mówili ci, na których zstąpił Duch Święty, z wyjątkiem stwierdzenia, że nie mówili oni ani językiem aramejskim, ani hebrajskim, ani greckim lub łacińskim. Można więc przypuszczać, że chodziło tutaj raczej o glosolalię, czyli o mówienie językami niezrozumiałymi dla słuchaczy ${ }^{47}$. Warto jednocześnie odnotować pewne różnice wobec Pawłowej prezentacji glosolali. W 1 Kor 12-14 Paweł pisał o osobach już ochrzczonych, które były częścią Kościoła, a glosolalia stanowiła tylko swego rodzaju ukazanie mocy Ducha Świętego, który już zamieszkiwał w ochrzczonych od momentu przyjęcia chrztu. Paweł przedstawia więc glosolalię jako dar udzielony ku zbudowaniu osoby, która go otrzymała $(14,4)$ a nie całej wspólnoty. W Cezarei mamy do czynienia z sytuacją zupełnie inną, kiedy to dar języków otrzymują osoby jeszcze nieochrzczone. Glosolalia jawi się tutaj jako zewnętrzny znak przyjścia Ducha Świętego, a jego cel jest wyraźnie eklezjalny, tzn. został dany Piotrowi i judeo-chrześcijanom, by ukazać działanie Boga dla dobra pogan. Chodziło więc o to, aby dopuścić do chrztu i do wspólnoty Kościoła pogan, którzy nie należeli do narodu wybranego. Choć zazwyczaj mieliśmy do czynienia z sekwencją wydarzeń: nawrócenie na chrześcijaństwo (= uznanie Jezusa za Mesjasza i Syna Bożego), chrzest, przyjście Ducha Świętego, tutaj, ze względu na wyjątkowość sytuacji porządek zostaje odwrócony: słuchanie Ewangelii, przejęcie jej wiarą, glosolalia, chrzest.

47 Por. Dąbrowski, Dzieje Apostolskie, s. 313; Munck, The Actes of the Apostles, s. 95-96; Weiser, Die Apostelgeschichte, s. 145; Pesch, Die Apostelgeschichte, s. 187. 
Było to jednak wydarzenie pojedyncze i wyjątkowe, które nigdy nie powtórzyło się w dziejach Kościoła w przyszłości ${ }^{48}$.

\subsection{Dzieje Apostolskie 19,1-7 - dar języków w Efezie}

Kolejną wzmiankę o mówieniu językami znajdujemy w Dz 19,1-7. Kiedy Paweł dociera do Efezu i znalazł tam jakichś uczniów, zapytał ich, czy otrzymali Ducha Świętego, gdy przyjęli chrzest. Gdy ci odpowiedzieli, że nawet nie słyszeli o istnieniu Ducha Świętego, więc dopytywał ich jak chrzest przyjęli. Kiedy okazało się, że przyjęli chrzest Janowy, Paweł wyjaśnił im różnicę pomiędzy Janowym chrztem nawrócenia a chrztem w imię Jezusa, wtedy "przyjęli chrzest w imię Pana Jezusa”. Gdy zaś po chrzcie Paweł nałożył na nich ręce (кaì

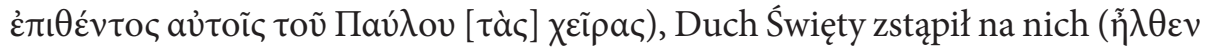

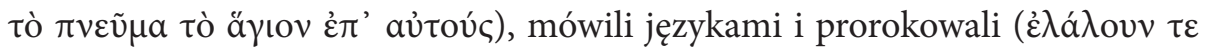

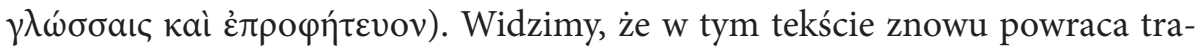
dycyjny porządek wydarzeń: chrzest, nałożenie rąk, przyjście Ducha Świętego ukazane zewnętrznie w formie mówienia językami i prorokowania. Owo mó-

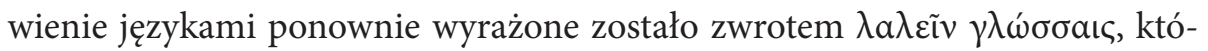
ry jest kluczowym wyrażeniem używanym przez Pawła. Mówienie językami

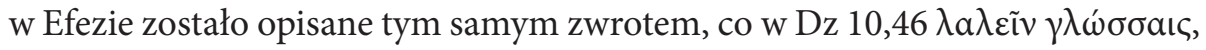

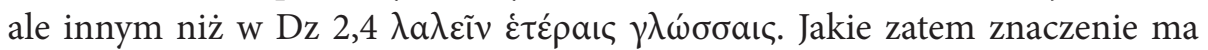
w tym kontekście owo $\lambda \alpha \lambda \varepsilon \tilde{v} v \gamma \lambda \omega ́ \sigma \sigma a \iota \varsigma$ ? Ponieważ zwrot jest dokładnie taki sam jak w 1 Kor 12-14 i Dz 10,46, więc najbardziej prawdopodobne wydaje się, że chodzi tutaj również o glosolalię ${ }^{49}$. Wydarzenie z Efezu jest podobne do tego w Cezarei, gdyż w obydwu przypadkach glosolalia jest oznaką przyjścia Ducha Świętego po przyjęciu wiary w Jezusa Chrystusa. Różni się jednak tym, że tutaj mówienie językami pojawia się po chrzcie i nałożeniu rąk. O ile Paweł postrzegał glosolalię jako dar udzielony ku zbudowaniu tego, kto go otrzymał, w Dziejach Łukasz chce ukazać, że inicjacja chrześcijańska dokonywana przez chrzest i apostolskie nałożenie rąk niesie ze sobą wylanie Ducha Świętego, czego nie czynił chrzest Janowy. Jak widzimy, Paweł ograniczał użyteczności glosolalii

48 Por. Vanhoye, I carismi, s. 100-101.

49 Por. ibidem, s. 101; Dąbrowski, Dzieje Apostolskie, s. 399; Munck, The Actes of the Apostles, s. 178-181; Weiser, Die Apostelgeschichte, s. 256; Pesch, Die Apostelgeschichte, s. 278. 
tylko do osoby nią obdarowanej, natomiast w tekstach Łukasza ma ona również użyteczność wspólnotową, kościelną. Ma ona przekonać widzów i słuchaczy, że wiara, chrzest i nałożenie rąk prowadzą do wylania Ducha Świętego, czego znakiem zewnętrznym jest właśnie glosolalia.

\section{Ewangelia Marka 16,9-20 - zapowiedź daru mówienia językami}

Ostatnim tekstem nowotestamentalnym, w którym pojawia się mówienie językami, jest zakończenie Ewangelii Marka 16,17. Fragment Mk 16,9-20 nastręcza wiele trudności, gdyż nie ma go w kodeksie Synaickim i Watykańskim, a także nie znają go niektórzy Ojcowie Kościoła jak Euzebiusz czy Hieronim, to jednak zawiera go przeważająca liczba najpoważniejszych rękopisów. W Mk

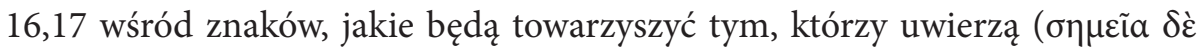

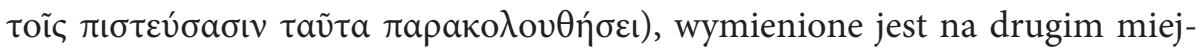

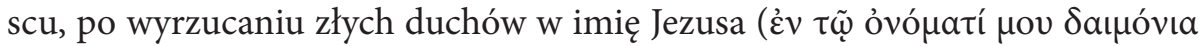

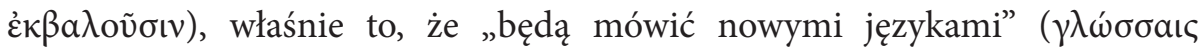
$\lambda \alpha \lambda \eta ́ \sigma o v \sigma ı v$ kaıvaĩs). Tekst nie jest do końca jasny, gdyż niektóre rękopisy nie zawierają słowa kaıvaĩc. Niektórzy badacze przypuszczają, że kaıvaĩ byłoby

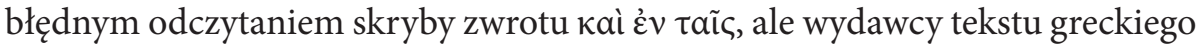
odrzucają takie przypuszczenia ${ }^{50}$. Jak więc rozumieć owo kaıvaĩ ? Wspominany już tutaj wielokrotnie Scippa jest przekonany, że zwrot ten należy interpretować w świetle Dz 2,4 gdzie, jak pamiętamy, pojawia się zwrot étépaıc. Języki „nowe” więc to byłyby języki ,inne/obce”, ale rzeczywiście istniejące i zrozumiałe, natomiast „nowe” w tym sensie, że niezrozumiałe dla ówczesnych chrześcijan, którzy ich nie znali ${ }^{51}$. Vanhoye kwestionuje takie rozumienie tekstu, podkreślając, że zapowiedź z Mk 16,17 byłaby podobna do Dz 2,4 i wtedy kaıvaĩ trzeba by rozumieć jako synonim étépaıৎ, gdyby ksenoglosja rzeczywiście była obiecana apostołom do ich posługi. Z niczym takim jednak nie mamy tutaj do czynienia, a wydarzenie Pięćdziesiątnicy było jednostkowe i niepowtarzalne. Co więcej, owo mówienie nowymi językami ma być znakiem rozpoznawczym dla wierzących, a nie dla ewangelizowania pogan, co raczej wskazuje na jego rozumienie jako glosolali. Sam termin kaıvaĩs sugeruje nowość całkowitą, czyli język, który

\footnotetext{
50 Por. Aland, Novum Testamentum Graece, s. 149.

51 Por. Scippa, La glossolalia, s. 157.
} 
nie istniał wcześniej ${ }^{52}$. Sam z siebie ten argument nie wystarczy, moim zdaniem, do uzasadnienia, że w tekście chodzi o glosolalię. Jeśli bowiem rozumiemy go jako prorocką zapowiedź misji uczniów, to z dzisiejszej perspektywy widzimy, że mówią oni nowymi językami realnie istniejącymi i zrozumiałymi, jak np. język polski, który w czasach Jezusa i apostołów jeszcze nie istniał. A wtedy byłaby to zapowiedź bardziej ksenoglosji niż glosolalii. Fragment z Ewangelii Marka jest bardzo krótki, więc trudno tutaj o jakieś ostateczne wnioski. Na pewno to, co w nim uderza, to brak jakiegokolwiek odniesienia do Ducha Świętego, choć dar języków jest wyraźnie połączony z przepowiadaniem i wiarą w schemat: głoszenie Ewangelii, wiara, chrzest i mówienie językami jako jeden ze znaków wiary. A jeśli mówienie językami ma być znakiem wiary, to wtedy propozycja Vanhoye, aby widzieć tutaj glosolalię wydaje się bardziej przekonująca. Trudno bowiem sobie wyobrazić, aby mówienie nowym językiem, istniejącym i zrozumiałym było takim znakiem.

\section{Bibliografia}

\section{Źródła}

Barbara et Kurt Aland, Novum Testamentum Graece, Stuttgart: Deutsche Bibelgesellschaft $1993^{27}$.

Biblia Tysiąclecia, wyd. V, Poznań: Pallottinum 2014.

\section{Opracowania}

Behm J., $\gamma \lambda \tilde{\omega} \sigma \sigma \alpha$, w: red. G. Kittel, G. Friedrich, Theological Dictinary of the New Testament, vol. I, Grand Rapids 1969, s. 719-727.

Currie S.D., Speaking of the Tongues: Early Evidence Outside the New Testament, Interpretation 19 (1965) 274-294.

Collins R.F., First Corinthians, Collegville 1999.

Dąbrowski E., Dzieje Apostolskie, Poznań 1961.

Dąbrowski E., Listy do Koryntian, Poznań 1965.

Dautzenberg G., Glossolalie, w: Reallexikon für Antike und Christentum, vol. XI, red. F.J. Dölger, Stuttgart 1981, s. 225-246.

Davis J.G., Pentecost and Glossolalia, Journal of Theological Studies 3 (1952) s. 228-231.

52 Por. Vanhoye, I carismi, s. 101. 
Ensley E., A Brief History of Jubilation, w: The Compete Library of Christian Worship, vol. 4, red. R.E. Webber, Peabody 1994, s. 276-298.

Farrar F.W., Life and Work of St. Paul, New York 1880.

Fitzmyer J., First Corinthians, New Haven-London 2008.

Forbes C., Prophecy and Inspired Speech in Early Christianity and its Hellenistic Environment, Tubingen 1995.

Fung R., Ministry, Community and Spiritual Gifts, Evangelical Quarterly 56 (1984) s. 3-20.

Gundry R.H., Ecstatic Utterance, Journal of Theological Studies NS 17 (1966) s. 299-307 .

Haacker K., Das Pfingstwunder als exegetisches Problem, w: ed. O. Bocher, Verborum Veritas. Festschrift G. Stahlin, Wuppertal 1970, s. 125-131.

Harrington D.J., Charism and Ministry: The Case of Apostle Paul, Chicago Studies 24 (1985) s. 245-257.

Hasel G., Speaking in Tongues: Biblical Speaking in Tongues and Contemporary Glossolalia, Berrien Spirngs 1991).

Heckel H., Paulus und die Charismatiker, Theologische Beitrag 23 (1992) s. 117-138.

Hodges Z.C., The Purpose of Tongues, Bibliotheca Sacra 120 (1963) s. 226-233.

Horlsey R.A., 1 Corinthians, Nashivlle 1998.

Lyonnet S., De glossolalia Pentecostes ejusque significatione, Verbum Domini 24 (1944) s. $65-75$.

Keener C.S., 1-2 Corinthians, Cambridge 2005.

Kobyliński A., Etyczne aspekty współczesnej pentekostalizacji chrześcijaństwa, Studia Philosophie Christianae 50 (2013) 3, s. 93-130.

Kopaliński W., Słownik wyrazów obcych i zwrotów obcojęzycznych, Warszawa 1983.

Kossowski M., Czym jest dar języków? Studium egzegetyczne Dz 2,1-13, Biblica et Patristica Thorunensia 7 (2014) 2, s. 123-137. DOI: http://dx.doi.org/10.12775/ BPTh.2014.012.

Lindemann A., Der Erste Korintherbrief, Tubingen 2000.

Macchia F.D., Tongues and Prophecy. A Pentecostal Perspective, Concilium 3 (1996) s. 63-69.

Malz J., W sprawie daru języków, w: Duch i Oblubienica. Materiały z III Forum popularyzacji teologii i kultury chrześcijańskiej (Wrocław-Leśnica) 12 grudnia 1998 r., red. M. Rosik, S. Rosik, Wrocław 1999, s. 17-21.

Munck J., The Actes of the Apostles, Garden City 1967.

Nardoni E., The Concept of Charism in Paul, Catholic Biblical Quarterly 55 (1993) s. $68-80$.

Orr W.F., Walther J. A., 1 Corinthians, Garden City 1976.

Perkins P., 1 Corinthians, Grand Rapids 2012.

Pesch R., Die Apostelgeschichte, Zurich 1986.

Radziwiołek Z., Dary Ducha Świętego w życiu chrześcijanina. Studium biblijne na podstawie Corpus Paulinum, Legnica 2006. 
Rosik M., Zaczęli mówić rozmaitymi językami (Dz 2,4). Rozumienie daru języków $w$ pierwszych wiekach chrześcijaństwa, Biblica et Patristica Thoruniensia 1 (2008) s. 220-228. DOI: http://dx.doi.org/10.12775/BPTh.2008.011.

Rosik M., Pierwszy List do Koryntian, Częstochowa 2009.

Rosik M., Dar języków. Biblia, historia, najpiękniejsze świadectwa, Kraków 2015.

Ruiz Gonzales J.M., Glossolalia, w: Enciclopedia della Bibbia, t. 3, Torino 1970, kol. 1307-1308.

Samarin W.J., Tonques of Men and Angels. The Religious Language of Pentecostalism, New York 1972.

Sanger D., $\gamma \lambda \tilde{\omega} \sigma \sigma \alpha, \mathrm{w}$ : Theological Biblical Lexicon of the New Testament, II, New York 2000, s. 1918-1923.

Schrage W., Der erste Brief an die Korinther, Zurich 1999.

Scippa V., La glossolalia nel Nuovo Testamento. Ricerca esegetica secondo il metodo storico-critico e analitico-strutturale, Napoli 1982.

Siemieniewski A., Dary duchowe $w$ dawnych wiekach Kościoła. „Nie zaniedbuj w sobie charyzmatu" (1 Tm 4,14), Wrocław 2005.

Siemieniewski A., Czy Kościół pierwszych wieków znał modlitwę w językach?, w: http:// www.apologetyka.katolik.pl (dostęp 06.06.2020).

Siemieniewski A., Kiwka M., Języki z ognia. Dar języków w Biblii, historii i we współczesności Kościoła, Wrocław 2017.

Spittler R.P., Glossolalia, w: red. S.M. Burgess, E.M. van der Maas (red.), The New Dictionary of Pentecostal and Charismatic Movements. Revised and Expanded Edition, Grand Rapids 2002, s. 670.

Stendahl K., Glosolalia - The New Testament Evidence, w: Paul among Jews and Gentiles, red. K. Stendahl, London 1977, s. 110-115.

Sullivan F.A., Charyzmaty i Odnowa Charyzmatyczna. Studium biblijne i teologiczne, Warszawa 1986.

Thiselton A.C., The First Epistle to the Corinthians: a Commentary on the Greek Text, Grand Rapids 2000.

Vanhoye A., I carismi nel Nuovo Testamento, Roma 1994.

Wedderburn A.J.M., Romans 8.26-Towards a Theology of Glossolalia?, Scottish Journal of Theology 28 (1975) s. 369-377.

Weiser A., Die Apostelgeschichte, Gutersloh 1981.

Wolf Ch., $\Lambda \alpha \lambda \varepsilon \tilde{\varepsilon} v \gamma \lambda \omega \sigma \sigma \alpha \iota$ in the Acts of the Apostles, w: A. Christopherson, C. Claussen, J. Frey, B. Longencker (eds), Paul, Luke and the Graeco-Roman World. Essays in Honour of Alexander J.M. Wedderburn, London-New York 2003, s. 189-201. 